\title{
ANALISIS KEBIJAKAN STANDAR KOMPETENSI LULUSAN DAN STANDAR ISI PENDIDIKAN AGAMA ISLAM DALAM KURIKULUM NASIONAL
}

\author{
Neneng Sunengsih \\ Sekolah Tinggi Ilmu Tarbiyah Islamic Village Tangerang \\ nenengsunengsih.stit@gmail.com
}

\begin{abstract}
The substance of Islamic education is reflected in the substance of the formulation of national education goals, namely "people who believe in and fear God Almighty and noble character", in the perspective of religions that people who believe, have faith, and have good morals are a reality that from the beginning became projections are presented religious education because in an effort can be achieved with religious education, especially PAI for Muslims. Basically, the teachings of Islam consist of Aqeedah, Sharia, and Morals. Of the three spheres of Islamic education, the school then unites as a subject of Islamic Religious Education which includes elements of aqeedah, morals, al-Qur'an, Hadith, History, and Fiqh. this certainly must be reviewed regarding government policies regarding curriculum content and Graduation Competency Standards (SKL) of Islamic Religious Education in schools so that the core objectives of Islamic education can be achieved. The method used in this research is a literature study with a descriptive qualitative approach and critical analysis of Islamic Religious Education policies in Indonesia sourced from some primary literature. The result is that the status of Islamic Religious Education is integrated into the national curriculum as a subject that is mandatory for all levels of education and in the renewal of moral education as the main objective of Islamic education has now become a necessity for every subject.
\end{abstract}

Keywords: Islamic Religious Education; National Curriculum

\begin{abstract}
ABSTRAK
Substansi pendidikan Islam yang tercermin dalam substansi rumusan tujuan pendidikan nasional, yaitu "manusia yang beriman dan bertakwa kepada Tuhan Yang Maha Esa dan akhlak mulia", dalam perspektif agama-agama bahwa manusia yang beriman, bertakwa, dan berakhlak mulia adalah kenyataan yang sejak awal menjadi proyeksi disajikan pendidikan agama, karena secara ikhtiar dapat dicapai dengan pendidikan agama, khususnya PAI bagi umat Islam. Secara pokok ajaran Islam itu terdiri dari Akidah, Syariah dan Akhlak. Dari ketiga lingkup pendidikan Islam tersebut, dalam sekolah kemudian menyatu sebagai sebuah mata peelajaran Pendidikan Agama Islam yang di dalamnya mecakup unsur aqidah, akhlak, Al-Qur'an, Hadits, Sejarah, serta Fiqh. hal ini tentu haru ditinjau mengenai kebijakan pemerintah tentang isi kurikulum serta Standar Kompetensi Kelulusan (SKL) Pendidikan Agama Islam di sekolah sehingga tujuan inti pendidikan Islam dapat tercapai. Metode yang digunakan dalam penelitian ini adalah studi pustaka dengan pendekatan kualitatif deskriptif serta analisis kritis terhadap kebijakan Pendidikan Agama Islam di Indonesia yang bersumber dari beberapa literatur
\end{abstract}


primer. Hasilnya adalah bahwa status Pendidikan Agama Islam terintegrasi dalam kurikulum nasional sebagai sebuah mata pelajaran yang sifatnya wajib bagi seluruh jenjang pendidikan serta dalam pembaharuannya pendidikan akhlak sebagai tujuan utama pedidikan Islam sekarang telah menjadi keharusan setiap mata pelajaran.

\section{Kata Kunci: Pendidikan Agama Islam, Kurikulum Nasional}

\section{PENDAHULUAN}

Bangsa Indonesia sekarang ini masih memiliki berbagai macam persoalan, baik kenegaraan dan kemasyarakatan hingga hubungan internasionalnya. Selain masih banyaknya kasus-kasus korupsi yang terungkap, meningkatnya tindak kriminal, kekerasan, anarkisme, premanisme, konsumsi minuman keras, dan narkoba sudah melanda di kalangan pelajar dan mahasiswa. Masyarakat kita juga cenderung pada masyarakat kepentingan, bukan tipe masyarakat yang guyub/gotong royong. Maka yang tampak sekarang adalah konflik-konflik kepentingan, baik konflik kepentingan individu, kelompok, agama, etnis, politik maupun kepentingan lainnya.

Krisis multidimensial menjadi ancaman bagi kalangan anak muda. Dari hasil kajian berbagai disiplin dan pendekatan, tampaknya ada kesamaan pandangan bahwa segala macam krisis itu berpangkal dari krisis akhlak atau moral. Krisis ini, secara langsung atau tidak berhubungan dengan persoalan pendidikan. Kontribusi pendidikan dalam konteks ini adalah pembangunan mentalitas manusia yang merupakan produknya. Ironisnya, krisis tersebut menurut sementara pihak dipandang disebabkan oleh kegagalan pendidikan agama, termasuk di dalamnya pendidikan agama Islam. ${ }^{1}$

\footnotetext{
${ }^{1}$ Muhaimin, Wacana Pengembangan Pendidikan Islam. (Yogyakarta: Pustaka Pelajar, 2003), hlm. 18,

Sedangkan menurut pendapatnya Ahmad Tafsir, bahwa selama ini kegagalan pendidikan yang menyangkut etika dan moral selalu dituduhkan kepada pendidikan agama, padahal seharusnya pendidikan etika dan moral tidak hanya menjadi tanggung jawab dari pendidikan agama saja. Bahwah seperti diketahui di sekolah pendidikan agama (sebagai mata pelajaran) seakan-akan berhadapan dengan sekian banyak pelajaran yang lainnya, dan ironisnya pendidikan karakter yang menjadi tujuan pendidikan Agama tidak terinternalisasi dalam pembelajaran mata pelajaran yang lain. Disampaikan pada seminar yang bertemakan Pengembangan Pendidikan Agama Islam Berbasis Multidisipliner pada tanggal 6 November 2014, di Pasca Sarjana UIN Maula Malik Ibrahim Malang.
} 
Azyumardi Azra sepertinya kurang sependapat terhadap tuduhan tersebut, menurutnya tinggi rendahnya tindak kriminal (seperti korupsi di atas) tidak banyak terkait dengan agama, tetapi justru lebih disebabkan karena: (1) lemahnya penegakan hukum; (2) mewabahnya gaya hidup hedonistik; (3) kurang adanya keteladanan dari pejabat-pejabat politik dalam memberantas korupsi dan penyakit sosial lainnya. Menurutnya, tidak adil apabila mengkambinghitamkan pendidikan Agama. $^{2}$

Muhaimin juga juga kurang sependapat bahwa timbulnya krisis akhlak atau moral hanya disebabkan karena kegalalan pendidikan agama. Menurutnya, kegiatan pendidikan merupakan suatu proses penamaan dan pengembangan seperangkat nilai dan norma yang implisit dalam setiap bidang studi sekaligus guru pengampunya, maka tugas pendidikan akhlak menurutnya adalah tidak hanya menjadi tanggung jawab guru PAI saja, akan tetapi semua guru mata pelajaran yang ada di dalam satuan pendidikan tersebut. Misalnya ada anak didik yang terlibat Narkoba, hal ini tidak berarti kegagalan guru PAI saja, akan tetapi juga merupakan kegagalan dari guru IPA, IPS, dan PPKN dan lainnya. Kalau ada anak didik yang hidupnya boros, juga merupakan kegagalan guru matematika dan ekonomi, dan sebagainya. ${ }^{3}$

Dari pendapat dua tokoh pendidikan di atas dapat disimpulkan bahwa, krisis moral dan akhlak anak didik tidak disebabkan oleh kegagalan guru agama saja, akan tetapi kegagalan semua guru yang ada pada satuan pendidikan tersebut. Oleh karena itu, kegiatan pendidikan di sekolah baik melalui pembelajaran di dalam kelas maupun di luar kelas, tidak boleh lepas dari nilai-nilai karakter. Isi dan materi kurikulum yang diberikan kepada peserta didik pun secara implisit akan memuat transmisi nilai-nilai karakter, yang terwujud sebagai bagian dari kurikulum formal maupun melalui kurikulum tersembunyi (hiden curriculum).

${ }^{2}$ Azumardi Azra, Agama dan Pemberantasan Korupsi. (Kompas, September 2003), hlm. 19

${ }^{3}$ Muhaimin, Pengembangan Kurikulum Pendidikan Agama Islam di Sekolah, Madrasah, Dan Perguruan Tinggi, (Jakarta: PT. RajaGrafindo, 2010), hlm. 19-20 
Berdasarkan amanat UU pendidikan nasional yang telah diatur dalam UU Sistem Pendidikan Nasional nomor 20 tahun 2003. Dalam UU tersebut pendidikan didefinisikan sebagai usaha sadar dan terencana untuk mewujudkan suasana belajar dan proses pendidikan agar peserta didik secara aktif mengembangkan potensi dirinya untuk memiliki kekuatan spiritual keagmaan, pengendalian diri, kepribadian, kecerdasan, akhlak mulia, serta ketrampilan yang diperlukan dirinya, masyarakat, bangsa, dan negara. Selain itu, dijelaskan pula bahwa pendidikan nasional bertujuan untuk berkembangnya potensi peserta didik agar menjadi manusia yang beriman dan bertakwa kepada Tuhan yang Maha Esa, berkahlak mulia, sehat, berilmu, cakap, kreatif, mandiri, dan menjadi warga negara yang demokratis serta bertanggung jawab. ${ }^{4}$

Dari uraian di atas, kiranya penelitian mengenai kebijakan pemerintah tentang isi kurikulum serta Standar Kompetensi Kelulusan (SKL) Pendidikan Agama Islam (PAI) sangatlah penting. Guna membuktikan apakah isi atau materi kurikulum saat ini sudah memenuhi harapan atau belum, karena di dalam kehidupan masyarakat masih banyak permasalah-permasalah sebagaimana contoh yang sudah disebutkan di atas tadi. Jika krisis akhlak dan moral merupakan inti dari tanggung jawab pendidikan agama Islam, maka perlu ditelaah dengan seksama dan dianalis secara kritis yang menyebabkan titik lemah dari pendidikan agam Islam terutama pada isi materi kurikulum Pendidikan Agama Islam.

\section{HASIL DAN PEMBAHASAN}

Kurikulum pendidikan nasional baik Kurikulum Tingkat Satuan Pendidikan (KTSP) maupun Kurikulum 2013 (K13) yang berlandaskan pada UU No. 20 Tahun 2003 tetang sistem pendidikan Nasional dan PP No. 19 Tahun 2005 tentang standar nasional pendidikan dalam KTSP dan PP No. 32 Tahun 2013 tentang perubahan atas PP No 19 tahun 2005 dalam K13 menempatkan Pendidikan Agama sebagai Mata Pelajaran wajib dalam setiap jenjang

${ }^{4}$ Undang-undang RI. No. 20 tahun 2003, Tentang Sistem Pendidikan Nasional. (Bandung: Citra Umbara, 2003), Hlm. 51 
pendidikan. ${ }^{5}$ Dari data tersebut terlihat betapa penting peranan Pendidikan Agama dalam pendidikan di Indonesia. Sehingga perlu kita cermati bersama bagaimana Pendidikan Agama (dalam hal ini Pendidikan Agama Islam) dalam pendidikan nasional.

\section{a. Ruang Lingkup Pendidikan Agama Islam Dalam Kurikulum Nasional}

Substansi pendidikan Islam yang tercermin dalam substansi rumusan tujuan pendidikan nasional, yaitu "manusia yang beriman dan bertakwa kepada Tuhan Yang Maha Esa dan akhlak mulia," 6 dalam perspektif agama-agama bahwa manusia yang beriman, bertakwa, dan berakhlak mulia adalah kenyataan yang sejak awal menjadi proyeksi disajikan pendidikan agama, karena secara ikhtiar dapat dicapai dengan pendidikan agama, khususnya PAI bagi umat Islam. Secara normative, karena itu adalah kewajiban umat Islam untuk melakukan regenerasi kader-kader Islam yang memahami ajaran-ajaran Agama Islam. Secara yuridis, karena UUD 1945 memandang itu bagian dari hak warga Negara. Secara psikologis kebutuhan dasar beragama (berpendidikan agama) merupakan salah satu dari banyak kebutuhan dasar manusia, dan secara sistemik pengembangan manusia Indonesia yang beriman dan bertakwa kepada Tuhan YME serta berakhlak mulia merupakan tujuan utama pendidikan Islam dan pendidikan nasional. Ini berarti bahwa pendidikan Islam merupakan satu kesatuan yang integral dari pendidikan nasional. ${ }^{7}$

Dalam kaitannya dengan pendidikan agama Islam sebagai suatu kesatuan dari pendidikan nasional, maka terlebih dahulu haruslah mengetahui ruang lingkup dari pendidikan islam itu sendiri. Menurut Ramayulis bahwa ruang lingkup PAI meliputi keserasian, keselarasan, dan keseimbangan antara manusia dengan Allah

\footnotetext{
${ }^{5}$ Peraturan Pemerintah Republik Indonesia Nomor 19 Tahun 2005 Tentang Standar Nasional Pendidikan Bagian Kedua Tentang Kerangka Dasar Dan Struktur Kurikulum Pasal 6 Ayat 1 poin a dan Ayat 2 serta dalam Peraturan Pemerintah Republik Indonesia Nomor 32 Tahun 2013 Tentang Perubahan Atas Peraturan Pemerintah Nomor 19 Tahun 2005 Tentang Standar Nasional Pendidikan pada Bagian Keempat Struktur Kurikulum Satuan Pendidikan dan Program Pendidikan pasal $77 \mathrm{G}$ hingga $77 \mathrm{~K}$

${ }^{6}$ Undang-undang RI. No. 20 tahun 2003, Ibid.

${ }^{7}$ Abd. Halim Soebahar, Kebijakan Pendidikan Islam dari Ordinasi Guru Sampai UU Sisdiknas, (Jakarta: Rajawali Pres, 2013)
} 
SWT, dengan sesama manusia, dengan dirinya sendiri dan dengan mahluk lain dan lingkungannya. ${ }^{8}$

Sedangkan pendapat lain mengatakan bahwa secara umum tujuan pendidikan agama islam adalah untuk membentuk peserta didik yang beriman dan bertaqwa kepada Allah SWT serta berakhlak mulia. Hal ini sesuai dengan apa yang dikemukakan oleh beberapa tokoh pendidikan agama islam seperti $\mathrm{Al}$ Attas"menjelaskan bahwa tujuan pendidikan Islam adalah untuk menjadi manusia yang baik", kemudian al-Abrasyai menjelaskan bahwa "tujuan pendidikan untuk membentuk manusia berakhlak mulia. Kemudian dalam konfrensi dunia Islam pertama tentang pendidikan Islam tahun 1975 berkesimpulan bahwa tujuan umum pendidikaan Islam adalah manusia yang menyerahkan diri kepada Allah secara mutlak . Secara lebih rinci Al-Abrasy menjelaskan bahwa tujuan akhir pendidikan Islam adalah 1) pembinaan akhlak; 2) menyiapkan anak didik untuk hidup didunia dan akhirat; 3) penguasaan ilmu; dan 4) keterampilan bekerja didalam masyarakat. Berbagai kriteria ini dijadikan sebagai pedoman dalam penjabaran Pendidikan Islam. ${ }^{9}$

Sementara itu secara garis besar bahwa dapat dikatakan pengajaran pendidikan agama Islam di sekolah mulai dari tingkat dasar sampai tingkat atas mempunyai target antara lain: ${ }^{10}$ pertama, Siswa taat beribadah, berzikir, berdoa serta mampu menjadi imam; kedua, Siswa mampu membaca al-Quran dan menuliskannya dengan benar serta berusaha memahami kandungan makna, terutama yang berkaitan dengan ilmu pengetahuan dan teknologi (Iptek); ketiga, Siswa memiliki kerpibadian muslim (berakhlak mulia); keempat, Siswa memahami, menghayati dan mengambil manfaat tarikh Islam; dan kelima, Siswa mampu menerapkan prinsip-prinsip muamalah dan syariah Islam dengan baik dalam kehidupan bermasyarakat, berbangsa dan bernegara berdasarkan Pancasila dan UUD 1945.

\footnotetext{
${ }^{8}$ Ramayulis, Metodologi Pengajaran Agama Islam, (Jakarta: Kalam Mulia, 2001), hlm. 104

${ }^{9}$ Tim Pengembang Ilmu Pendidikan, Ilmu dan Aplikasi Pendidikan,( Bandung:Fakultas Ilmu Pendikan ( FIP) Universitas Pendidikan Indonesia ( UPI ),2007 ), hlm.2-3

${ }^{10}$ Depdikbud, Peraturan Pelaksanaan Sistem Pendidikan Nasional, (Jakarta, Armas Duta Jaya, 1995), hlm. 3
} 
Berdasar uraian di atas dapat diketahui bahwa secara pokok ajaran Islam itu terdiri dari Akidah, Syariah dan Akhlak. Akidah berarti satu sistem kepercayaan, keyakinan dan keimanan. Syariah berarti satu sistem aturan ilahi yang mengatur hubungan manusia dengan Tuhan, dengan sesama manusia, dan dengan lingkungan hidup, yang secara umum pembahasannya mengenai ibadah dan muamalah. Sedangkan akhlak yaitu satu sistem tingkah laku/ perbuatan yang secara umum pembahasannya berkisar pada akhlak yang mahmudah dan madzmumah.

Dari ketiga lingkup pendidikan Islam tersebut, dalam sekolah kemudian menyatu sebagai sebuah mata peelajara Pendidikan Agama Islam yang didalamnya mecakup unsur aqidah, akhlak, al-Qur'an, Hadits, Sejarah, serta Fiqh. Sedangan pada madrasah masing-masing unsur PAI tersebut di menjadi mata pelajaran tersendiri. Sehingga pada hakikatnya bahwa pendidikan agama islam dalam kurikulum nasional menyangkut tiga aspek pendidikan yaitu Aqidah, Akhlak dan Syariah. ${ }^{11}$

Tentang pendidikan keagamaan, pada pasal 30 UU No. 20 tahun 2003 dinyatakan sebagai berikut;

Pendidikan keagamaan diselenggarakan oleh pemerintah dan/atau kelompok masyarakat dari pemeluk agama, sesuai dengan peraturan perundang-undangan, (2) pendidikan keagamaan berfungsi mempersiapkan peserta didik menjadi anggota masyarakat yang memahami dan mengamalkan nilai-nilai ajaran agamanya dan/atau menjadi ahli ilmu agama, (3) pendidikan keagamaan dapat diselenggarakan pada jalur pendidikan formal, nonformal, dan informal, (4) pendidikan keagamaan berbentuk pendidikan diniyah, pesantren, pasraman, pabhaya samanera, dan bentuk lain yang sejenis. ${ }^{12}$

\footnotetext{
${ }^{11}$ Abd. Halim Soebahar, Op.Cit.

${ }^{12}$ Undang-undang RI. No. 20 tahun 2003, Op.Cit.
} 
Penjelasan lebih lanjut mengenai Pendidikan Agama Islam dalam kurikulum nasional dijabarkan dalam struktur kurikulum satuan pendidikan sebagaimana berikut; ${ }^{13}$

1) Tingkat $\mathrm{SD}$

Tabel 1. tentang Struktur Kurikulum KTSP tingkat SD

\begin{tabular}{|c|c|c|c|c|}
\hline \multirow[b]{2}{*}{ Komponen } & \multicolumn{4}{|c|}{ Kelas dan Alokasi Waktu } \\
\hline & I & II & III & $\begin{array}{l}\text { IV, V, dan } \\
\text { VI }\end{array}$ \\
\hline \multicolumn{5}{|l|}{ A. Mata Pelajaran } \\
\hline 1. Pendidikan Agama & & & & 3 \\
\hline 2. Pendidikan Kewarganegaraan & & & & 2 \\
\hline 3. Bahasa Indonesia & & & & 5 \\
\hline 4. Matematika & & & & 5 \\
\hline 5. Ilmu Pengetahuan Alam & & & & 4 \\
\hline 6. Ilmu Pengetahuan Sosial & & & & 3 \\
\hline 7. Seni Budaya dan Keterampilan & & & & 4 \\
\hline $\begin{array}{l}\text { 8. Pendidikan Jasmani, Olahraga dan } \\
\text { Kesehatan }\end{array}$ & & & & 4 \\
\hline B. Muatan Lokal & & & & 2 \\
\hline C. Pengembangan Diri & & & & $2 *)$ \\
\hline Jumlah & 26 & 27 & 28 & 32 \\
\hline
\end{tabular}

*) Ekuivalen 2 jam pembelajaran

\section{2) Tingkat SMP}

Tabel 2. tentang Struktur Kurikulum KTSP tingkat SMP

\begin{tabular}{|l|c|c|c|}
\hline \multirow{2}{*}{ Komponen } & \multicolumn{3}{c|}{ Kelas dan Alokasi Waktu } \\
\cline { 2 - 4 } & VII & VIII & IX \\
\hline A. Mata Pelajaran & & & \\
\hline 1. Pendidikan Agama & 2 & 2 & 2 \\
\hline 2. Pendidikan Kewarganegaraan & 2 & 2 & 2 \\
\hline 3. Bahasa Indonesia & 4 & 4 & 4 \\
\hline 4. Bahasa Inggris & 4 & 4 & 4 \\
\hline 5. Matematika & 4 & 4 & 4 \\
\hline 6. Ilmu Pengetahuan Alam & 4 & 4 & 4 \\
\hline 7. Ilmu Pengetahuan Sosial & 4 & 4 & 4 \\
\hline 8. Seni Budaya & 2 & 2 & 2 \\
\hline 9. Pendidikan Jasmani, Olahraga dan Kesehatan & 2 & 2 & 2 \\
\hline 10. Keterampilan/Teknologi Informasi dan & 2 & 2 & 2 \\
\hline Komunikasi & & & \\
\hline B. Muatan Lokal & 2 & 2 & 2 \\
\hline C. Pengembangan Diri & $2 *)$ & $2 *)$ & $2 *)$ \\
\hline
\end{tabular}

${ }^{13}$ Lampiran Peraturan Menteri Pendidikan Nasional Nomor 22 Tahun 2006 tentang Standar Isi dan Lampiran Peraturan Menteri Pendidikan dan Kebudayaan Nomor 64 Tahun 2013 tentang Standar Isi. Lihat juga Herry Wisyastono, Pengembangan Kurikulum Di Era Otonomi Daerah, (Jakarta: PT. Bumi Aksara, 2014), Hlm. 88-161 
2*) Ekuivalen 2 jam pembelajaran

3) Tingkat SMA

STRUKTUR KURIKULUM KELAS X

Tabel 3. tentang Struktur Kurikulum KTSP tingkat SMA

\begin{tabular}{|c|c|c|}
\hline \multirow{2}{*}{ Komponen } & \multicolumn{2}{|c|}{ Alokasi Waktu } \\
\hline & Semester 1 & Semester 2 \\
\hline \multicolumn{3}{|l|}{ A. Mata Pelajaran } \\
\hline 1. Pendidikan Agama & 2 & 2 \\
\hline 2. Pendidikan Kewarganegaraan & 2 & 2 \\
\hline 3. Bahasa Indonesia & 4 & 4 \\
\hline 4. Bahasa Inggris & 4 & 4 \\
\hline 5. Matematika & 4 & 4 \\
\hline 6. Fisika & 2 & 2 \\
\hline 7. Biologi & 2 & 2 \\
\hline 8. Kimia & 2 & 2 \\
\hline 9. Sejarah & 1 & 1 \\
\hline 10. Geografi & 1 & 1 \\
\hline 11. Ekonomi & 2 & 2 \\
\hline 12. Sosiologi & 2 & 2 \\
\hline 13. Seni Budaya & 2 & 2 \\
\hline 14. Pendidikan Jasmani, Olahraga dan Kesehatan & 2 & 2 \\
\hline 15. Teknologi Informasi dan Komunikasi & 2 & 2 \\
\hline 16. Keterampilan /Bahasa Asing & 2 & 2 \\
\hline B. Muatan Lokal & 2 & 2 \\
\hline C. Pengembangan Diri & $2 *)$ & $2 *)$ \\
\hline Jumlah & 38 & 38 \\
\hline
\end{tabular}

$2 *)$ Ekuivalen 2 jam pembelajaran

Catatan: pada kelas XI dan XII di semua jurusan baik smester 1 atau smester 2 Pendidikan Agama Islam dialokasik 2 jam pembelajaran.

\section{4) Tingkat SD}

Tabel 4. tentang Struktur Kurikulum K-13 tingkat SD

\begin{tabular}{|l|l|l|l|l|l|l|l|l|l|}
\hline \multicolumn{2}{|c|}{ Mata Pelajaran } & \multicolumn{5}{|c|}{ Alokasi Waktu Per Minggu } \\
\cline { 3 - 9 } & I & II & III & IV & V & VI \\
\hline Kelompok A & 4 & 4 & 4 & 4 & 4 & 4 \\
\hline 1. & Pendidikan Agama & 4 & 5 & 5 & 6 & 5 & 5 & 5 \\
\hline 2. & Pendidikan Pancasiladan Kewarganegaraan & 8 & 9 & 10 & 7 & 7 & 7 \\
\hline 3. & Bahasa Indonesia & 5 & 6 & 6 & 6 & 6 & 6 \\
\hline 4. & Matematika & - & - & - & 3 & 3 & 3 \\
\hline 5. & Ilmu Pengetahuan Alam & - & - & - & 3 & 3 & 3 \\
\hline 6. & Ilmu Pengetahuan Sosial & & & & \\
\hline
\end{tabular}




\begin{tabular}{|l|l|l|l|l|l|l|l|}
\hline Kelompok B & 4 & 4 & 4 & 5 & 5 & 5 \\
\hline 1. & Seni Budaya dan Prakarya & 4 & 4 & 4 & 4 & 4 & 4 \\
\hline 2. & Pendidikan Jasmani, Olah Raga dan Kesehatan & $\mathbf{3 0}$ & $\mathbf{3 2}$ & $\mathbf{3 4}$ & $\mathbf{3 6}$ & $\mathbf{3 6}$ & $\mathbf{3 6}$ \\
\hline Jumlah Alokasi Waktu Per Minggu
\end{tabular}

5) Tingkat SMP

Tabel 5. tentang Struktur Kurikulum K-13 tingkat SMP

\begin{tabular}{|c|c|c|c|c|}
\hline \multirow{2}{*}{\multicolumn{2}{|c|}{ Mata Pelajaran }} & \multicolumn{3}{|c|}{ Alokasi Waktu Per Minggu } \\
\hline & & VII & VIII & IX \\
\hline \multicolumn{5}{|c|}{ Kelompok A } \\
\hline 1. & Pendidikan Agama dan Budi Pekerti & 3 & 3 & 3 \\
\hline 2. & Pendidikan Pancasila dan Kewarganegaraan & 3 & 3 & 3 \\
\hline 3. & Bahasa Indonesia & 6 & 6 & 6 \\
\hline 4. & Matematika & 5 & 5 & 5 \\
\hline 5. & Ilmu Pengetahuan Alam & 5 & 5 & 5 \\
\hline 6. & Ilmu Pengetahuan Sosial & 4 & 4 & 4 \\
\hline 7. & Bahasa Inggris & 4 & 4 & 4 \\
\hline \multicolumn{5}{|c|}{ Kelompok B } \\
\hline 1. & Seni Budaya & 3 & 3 & 3 \\
\hline 2. & Pendidikan Jasmani, Olah Raga, dan Kesehatan & 3 & 3 & 3 \\
\hline 3. & Prakarya & 2 & 2 & 2 \\
\hline $\mathbf{J u}$ & nlah Alokasi Waktu Per Minggu & 38 & 38 & 38 \\
\hline
\end{tabular}

6) Tingkat SMA

Tabel 6. tentang Struktur Kurikulum K-13 tingkat SMA

\begin{tabular}{|c|c|c|c|c|}
\hline \multirow{2}{*}{\multicolumn{2}{|c|}{ Mata Pelajaran }} & \multicolumn{3}{|c|}{$\begin{array}{l}\text { Alokasi Waktu } \\
\text { Per Minggu }\end{array}$} \\
\hline & & $\mathrm{X}$ & XI & $\overline{\mathrm{XII}}$ \\
\hline \multicolumn{5}{|c|}{ Kelompok A (Wajib) } \\
\hline 1. & Pendidikan Agama dan Budi Pekerti & 3 & 3 & 3 \\
\hline 2. & Pendidikan Pancasila dan Kewarganegaraan & 2 & 2 & 2 \\
\hline 3. & Bahasa Indonesia & 4 & 4 & 4 \\
\hline 4. & Matematika & 4 & 4 & 4 \\
\hline 5. & Sejarah Indonesia & 2 & 2 & 2 \\
\hline 6. & Bahasa Inggris & 2 & 2 & 2 \\
\hline \multicolumn{5}{|c|}{ Kelompok B (Wajib) } \\
\hline 7. & Seni Budaya & 2 & 2 & 2 \\
\hline 8. & Pendidikan Jasmani, Olahraga, dan Kesehatan & 3 & 3 & 3 \\
\hline 9. & Prakarya dan Kewirausahaan & 2 & 2 & 2 \\
\hline Jur & lah Jam Pelajaran Kelompok A dan B per minggu & 24 & 24 & 24 \\
\hline \multicolumn{5}{|c|}{ Kelompok C (Peminatan) } \\
\hline \multicolumn{2}{|c|}{ Mata Pelajaran Peminatan Akademik } & 18 & 20 & 20 \\
\hline \multicolumn{2}{|r|}{ Mata Pelajaran Peminatan Akademik danVokasi } & 24 & 24 & 24 \\
\hline \multicolumn{2}{|r|}{\begin{tabular}{lllll|} 
Jumlah Jam Pelajaran yang Harus ditempuh per \\
minggu
\end{tabular}} & 42 & 44 & 44 \\
\hline
\end{tabular}


Dari tabel di atas dapat dilihat bagaimana kebijakan terbaru dalam k13 memberikan porsi yang lebih banyak kepada pendidikan agama dan budi pekerti. Hal ini menandakan bahwa pendidikan agama dan budi pekerti yang selama ini dilakukan dalam KTSP dianggap kurang, sehingga pada K13 diberikan tambahan waktu untuk pelaksanaan pembelajaran pendidikan agama Islam dalam setiap jenjangnya.

\section{b. Standar Kompetensi Kelulusan (SKL) dan Standar Isi (SI) Pendidikan} Agama Islam Dalam Kurikulum Nasional

Dalam peraturan pemerintah RI No. 19 Tahun 2005 tentang Standar Nasional Pendidikan dikemukakan bahwa: "Standar kompetensi lulusan adalah kualifikasi kemampuan lulusan yang mencakup pengetahuan, sikap dan ketrampilan", secara garis besar standar kompetensi lulusan dapat dideskripsikan sebagai berikut: ${ }^{14}$

1) Standar kompetensi lulusan digunakan sebagai pedoman penilaian dalam penentuan kelulusan peserta didik yang meliputi kompetensi untuk seluruh mata pelajaran serta mencakup aspek pengetahuan, aspek sikap dan aspek keterampilan.

2) Standar kompetensi lulusan pada jenjang pendidikan dasar bertujuan untuk meletakan dasar kecerdasan, pengetahuan, kepribadian, akhlak mulia serta keterampilan untuk hidup mandiri dan pendidikan lebih lanjut.

Dalam menyusun kurikulum tentu harus memperhatikan dulu analisis kompetensi yang dibutuhkan untuk bisa melaksanakan tugas-tugas tertentu. Hasil analisis tersebut pada gilirannya menghasilkan Standar Kompetensi Lulusan (SKL).

Menurut Muhaimin dalam bukunya "Pengembangan kurikulum pendidikan agama Islam di sekolah, madrasah, dan perguruan tinggi” menyebutkan bahwa yang dimaksud Standar Kompetensi Lulusan (SKL) adalah seperangkat kompetensi lulusan yang dibakukan dan diwujudkan

14 E. Mulyasa, Kurikulum Tingkat SatuanPendidikanKemandirian Guru danKepalaSekolah, (Jakarta:Bumiaksara, cet I, 2008), Hlm. 26 
dengan hasil belajar peserta didik. ${ }^{15}$ Standar ini menurutnya harus dapat diukur dan diamati memudahkan pengambilan keputusan bagi dosen, tenaga kependidikan lain, peserta didik, orang tua, dan penentu kebijakan pendidikan. Standar bermanfaat sebagai dasar penilaian dan pemantauan proses kemajuan dan hasil belajar peserta didik.

Adapun tujuan Standar Kompetensi Lulusan (SKL) adalah sebagai berikut: ${ }^{16}$

1) Mewujudkan standar nasional dan standar institusional kompetensi kelulusan

2) Memberikan acuan dalam merumuskan kriteria, kerangka dasar pengendalian dan jaminan mutu lulusan

3) Memperkuat profesionalisme lulusan melalui standarisasi lulusan secara nasional dengan tetap memperhatikan tuntutan institusional, yaitu mewujudkan visi dan misi suatu lembaga.

Adapun contoh SKL di lembaga satuan pendidikan pada mata pelajaran PAI, yang diharapkan memiliki sifat sebagai berikut:

1) Menumbuhkan kekuatan akidah melalui pemberian, pemupukan, dan pengembangan pengetahuan, penghayatan, pengamalan, pembiasaan, serta pengalaman peserta dididk tentang agama islam sehingga menjadi manusia muslim yang terus berkembang keimanan dan ketakwaannya kepada Allah SWT.

2) Mewujudkan manusia Indonesia yang taat beragama dan berakhlak mulia yaitu manusia yang berpengetahuan, rajin beribadah, cerdas, produktif, jujur, adil, etis, berdisiplin, bertoleransi (tasamuh), menjaga keharmonisan secara personal dan social serta mengembangkan budaya agama dalam komunitas sekolah.

\footnotetext{
${ }^{15}$ Muhaimin, Pengembangan kurikulum pendidikan agama Islam di sekolah, madrasah, dan perguruan tinggi, (Jakarta: PT. RajaGrasindo, 2010), Hlm. 230

16 Mochtar Buchori, Ilmu Pendidikan \& Praktik Pendidikan Dalam Renungan. (Yogyakarta: Tiara Wacana, 1994), Hlm. 23
} 
Kemudian Standar Kompetensi Lulusan terdiri atas kriteria kualifikasi kemampuan peserta didik yang diharapkan dapat dicapai setelah menyelesaikan masa belajarnya di satuan pendidikan pada jenjang pendidikan dasar dan menengah. Untuk mengetahui ketercapaian dan kesesuaian antara Standar Kompetensi Lulusan dan lulusan dari masing-masing satuan pendidikan dan kurikulum yang digunakan pada satuan pendidikan tertentu perlu dilakukan monitoring dan evaluasi secara berkala dan berkelanjutan dalam setiap periode. Hasil yang diperoleh dari monitoring dan evaluasi digunakan sebagai bahan masukan bagi penyempurnaan Standar Kompetensi Lulusan di masa yang akan datang.

\section{1) Kompetensi Lulusan SD/MI/SDLB/Paket A}

Lulusan SD/MI/SDLB/Paket A memiliki sikap, pengetahuan, dan keterampilan sebagai berikut.

Tabel 7. tentang Kompetensi Lulusan SD/MI/SDLB/Paket A

\begin{tabular}{|c|l|}
\hline \multicolumn{2}{|c|}{ SD/MI/SDLB/Paket A } \\
\hline Dimensi & \multicolumn{1}{c|}{ Kualifikasi Kemampuan } \\
\hline Sikap & $\begin{array}{l}\text { Memiliki perilaku yang mencerminkan sikap orang beriman, berakhlak mulia, } \\
\text { berilmu, percaya diri, dan bertanggung jawab dalam berinteraksi secara efektif dengan } \\
\text { lingkungan sosial dan alam di lingkungan rumah, sekolah, dan tempat bermain. }\end{array}$ \\
\hline Pengetahuan & $\begin{array}{l}\text { Memiliki pengetahuan faktual dan konseptual berdasarkan rasa ingin tahunya tentang } \\
\text { ilmu pengetahuan, teknologi, seni, dan budaya dalam wawasan kemanusiaan, } \\
\text { kebangsaan, kenegaraan, dan peradaban terkait fenomena dan kejadian di lingkungan } \\
\text { rumah, sekolah, dan tempat bermain. }\end{array}$ \\
\hline Keterampilan & $\begin{array}{l}\text { Memiliki kemampuan pikir dan tindak yang produktif dan kreatif dalam ranah abstrak } \\
\text { dan konkret sesuai dengan yang ditugaskan kepadanya. }\end{array}$ \\
\hline
\end{tabular}

2) Kompetensi Lulusan SMP/MTs/SMPLB/Paket B

Lulusan SMP/MTs/SMPLB/Paket B memiliki sikap, pengetahuan, dan keterampilan sebagai berikut.

Tabel 8. tentang Kompetensi Lulusan SMP/MTs/SMPLB/Paket B

\begin{tabular}{|c|l|}
\hline \multicolumn{2}{|c|}{ SMP/MTs/SMPLB/Paket B } \\
\hline Dimensi & \multicolumn{1}{|c|}{ Kualifikasi Kemampuan } \\
\hline Sikap & $\begin{array}{l}\text { Memiliki perilaku yang mencerminkan sikap orang beriman, berakhlak mulia, } \\
\text { berilmu, percaya diri, dan bertanggung jawab dalam berinteraksi secara efektif } \\
\text { dengan lingkungan sosial dan alam dalam jangkauan pergaulan dan keberadaannya. }\end{array}$ \\
\hline
\end{tabular}




\begin{tabular}{|c|l|}
\hline & \\
\hline Pengetahuan & $\begin{array}{l}\text { Memiliki pengetahuan faktual, konseptual, dan prosedural dalam ilmu pengetahuan, } \\
\text { teknologi, seni, dan budaya dengan wawasan kemanusiaan, kebangsaan, kenegaraan, } \\
\text { dan peradaban terkait fenomena dan kejadian yang tampak mata. }\end{array}$ \\
\hline Keterampilan & $\begin{array}{l}\text { Memiliki kemampuan pikir dan tindak yang efektif dan kreatif dalam ranah abstrak } \\
\text { dan konkret sesuai dengan yang dipelajari disekolah dan sumber lain sejenis. }\end{array}$ \\
\hline
\end{tabular}

3) Kompetensi Lulusan SMA/MA/SMK/MAK/SMALB/Paket C

Lulusan SMA/MA/SMK/MAK/SMALB/Paket C memiliki sikap,

pengetahuan, dan keterampilan sebagai berikut.

Tabel 9. tentang Kompetensi Lulusan SMA/MA/SMK/MAK/SMALB/Paket C

\begin{tabular}{|c|l|}
\hline \multicolumn{2}{|c|}{ SMA/MA/SMK/MAK/SMALB/Paket C } \\
\hline Dimensi & \multicolumn{1}{|c|}{ Kualifikasi Kemampuan } \\
\hline Sikap & $\begin{array}{l}\text { Memiliki perilaku yang mencerminkan sikap orang beriman, berakhlak mulia, } \\
\text { berilmu, percaya diri, dan bertanggung jawab dalam berinteraksi secara efektif dengan } \\
\text { lingkungan sosial dan alam serta dalam menempatkan diri sebagai cerminan bangsa } \\
\text { dalam pergaulan dunia. }\end{array}$ \\
\hline Pengetahuan & $\begin{array}{l}\text { Memiliki pengetahuan faktual, konseptual, prosedural, dan metakognitif dalam ilmu } \\
\text { pengetahuan, teknologi, seni, dan budaya dengan wawasan kemanusiaan, kebangsaan, } \\
\text { kenegaraan, dan peradaban terkait penyebab serta dampak fenomena dan kejadian. }\end{array}$ \\
\hline Keterampilan & $\begin{array}{l}\text { Memiliki kemampuan pikir dan tindak yang efektif dan kreatif dalam ranah abstrak } \\
\text { dan konkret sebagai pengembangan dari yang dipelajari di sekolah secara mandiri. }\end{array}$ \\
\hline
\end{tabular}

Sedangkan Standar Isi untuk satuan Pendidikan Dasar dan Menengah yang selanjutnya disebut Standar Isi mencakup lingkup materi minimal dan tingkat kompetensi minimal untuk memcapai kompetensi lulusan minimal pada jenjang dan jenis pendidikan tertentu. Standar Isi memuat kerangka dasar, struktur kurikulum, beban belajar, kurikulum tingkat satuan pendidikan, dan kalender pendidikan/akademik. Dalam penjabarannya Standar Isi PAI dalam Kurikulum Nasional memiliki beberapa komponen pokok sebagaimana disebutkan dalam ruang lingkup Pendidikan Agama Islam dalam kurikulum nasional yang menyangkut, al-qur'an Hadis, Fikh, Akidah, Akhlak dan Sejarah. 
Tingkat Kompetensi dikembangkan berdasarkan kriteria; (1) Tingkat perkembangan peserta didik, (2) Kualifikasi kompetensi Indonesia, (3) Penguasaan kompetensi yang berjenjang. Selain itu Tingkat Kompetensi juga memperhatikan; tingkat kerumitan/kompleksitas kompetensi, fungsi satuan pendidikan, dan keterpaduan antar jenjang yang relevan. Berdasarkan pertimbangan di atas, Tingkat Kompetensi dirumuskan sebagai berikut:

Tabel 10. tentang Rumusan Tingkat Kompetensi Peserta Didik

\begin{tabular}{|c|c|c|}
\hline NO & TINGKAT KOMPETENSI & TINGKAT KELAS \\
\hline 1. & Tingkat 0 & TK/RA \\
\hline 2. & Tingkat 1 & 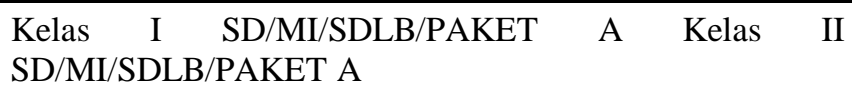 \\
\hline 3. & Tingkat 2 & $\begin{array}{llllll}\text { Kelas } & \text { III } & \text { SD/MI/SDLB/PAKET } & \text { A } & \text { Kelas } & \text { IV } \\
\text { SD/MI/SDLB/PAKET A } & & & & \end{array}$ \\
\hline 4. & Tingkat 3 & $\begin{array}{lccccc}\text { Kelas } & \mathrm{V} & \text { SD/MI/SDLB/PAKET } & \text { A } & \text { Kelas } & \text { VI } \\
\text { SD/MI/SDLB/PAKET A } & & & & \end{array}$ \\
\hline 5. & Tingkat 4 & $\begin{array}{l}\text { Kelas VII SMP/MTs/SMPLB/PAKET B } \quad \text { Kelas VIII } \\
\text { SMP/MTs/SMPLB/PAKET B }\end{array}$ \\
\hline 6. & Tingkat 4A & Kelas IX SMP/MTs/SMPLB/PAKET B \\
\hline 7. & Tingkat 5 & \begin{tabular}{lcccr} 
Kelas & X & \multicolumn{2}{c}{ SMA/MA/SMALB/SMK/MAK/ } & PAKET \\
C/PAKET & C & KEJURUAN & Kelas & XI \\
SMA/MA/SMALB/SMK/MAK/ & PAKET & C/PAKET & C \\
KEJURUAN & & & & \\
\end{tabular} \\
\hline 8. & Tingkat 6 & $\begin{array}{l}\text { Kelas XII SMA/MA/SMALB/SMK/MAK/ PAKET } \\
\text { C/PAKET C KEJURUAN }\end{array}$ \\
\hline
\end{tabular}

Keterangan:

SDLB, SMPLB, dan SMALB yang dimaksud hanya diperuntukkan bagi tuna netra, tuna rungu, tuna daksa, dan tuna laras yang intelegensinya normal.

Tingkat kompetensi disusun berdasarkan taksonomi struktur capaian belajar terobservasi (Structure of The Observed Learning Outcomes (SOLO) Taxonomy). Berdasarkan taksonomi ini, capaian belajar dikelompokan dalam 5 kategori yakni: Pre-Structural (0), Uni-Structural (1), Multi-Structural (2), Relational (3), dan Extended-Abstract (4 dan 5).

Di atas kategori Extended-Abstract secara teoritis ada tiga tingkat yang lebih kompleks yakni Psychodelia, Illumination, dan Creativity yang kesemua itu merupakan capaian belajar yang lebih abstrak. Berdasarkan hal 
tersebut, dikembangkan secara adaptif tingkat kompetensi menjadi 0, 1, 2, 3, 4, 5, dan 6. Masing-masing tingkat kompetensi mencakup 2 (dua) tingkat kelas, kecuali tingkat kompetensi 4A dan 6 hanya mencakup 1 (satu) tingkat kelas. Tingkat kompetensi 4A merupakan kemampuan peralihan jenjang pendidikaan dasar ke pendidikan menengah dan tingkat kompetensi 6 merupakan kemampuan peralihan pendidikan menengah ke jenjang pendidikan tinggi.

Setiap tingkat kompetensi berimplikasi terhadap tuntutan proses pembelajaran dan penilaian. Hal ini bermakna bahwa pembelajaran dan penilaian pada tingkat yang sama memiliki karakteristik yang relatif sama dan memungkinkan terjadinya akselerasi belajar dalam 1 (satu) tingkat kompetensi. Selain itu, untuk tingkat kompetensi yang berbeda menuntut pembelajaran dan penilaian dengan fokus dan penekanan yang berbeda pula. Semakin tinggi tingkat kompetensi, semakin kompleks intensitas pengalaman belajar peserta didik dan proses pembelajaran serta penilaian.

Uraian kompetensi inti untuk setiap tingkat kompetensi disajikan dalam tabel di bawah ini.

Tabel 11. Tingkat Kompetensi 1 (Tingkat Kelas I-II SD/MI/SDLB/PAKET A)

\begin{tabular}{|c|c|c|}
\hline KOMPETENSI & \multicolumn{1}{|c|}{ DESKRIPSI KOMPETENSI } \\
\hline Sikap Spiritual & $\begin{array}{l}\text { Menerima, menjalankan, dan menghargai ajaran agama yang } \\
\text { dianutnya }\end{array}$ \\
\hline Sikap Sosial & $\begin{array}{l}\text { Menunjukkan perilaku jujur, disiplin, tanggung jawab, santun, } \\
\text { peduli, dan percaya diri dalam berinteraksi dengan keluarga, teman, } \\
\text { dan guru }\end{array}$ \\
\hline Pengetahuan & $\begin{array}{l}\text { Memahami pengetahuan faktual dengan cara mengamati } \\
\text { (mendengar, melihat, membaca) dan menanya berdasarkan rasa } \\
\text { ingin tahu tentang dirinya, makhluk ciptaan Tuhan dan } \\
\text { kegiatannya, dan benda-benda yang dijumpainya di rumah dan di } \\
\text { sekolah }\end{array}$ \\
\hline Keterampilan & $\begin{array}{l}\text { Menyajikan pengetahuan faktual dalam bahasa yang jelas dan logis, } \\
\text { dalam karya yang estetis, dalam gerakan yang mencerminkan anak } \\
\text { sehat, dan dalam tindakan yang mencerminkan perilaku anak } \\
\text { beriman dan berakhlak mulia }\end{array}$ \\
\hline
\end{tabular}

Tabel 12. Tingkat Kompetensi 2 (Tingkat Kelas III-IV SD/MI/SDLB/PAKET A) 


\begin{tabular}{|c|l|}
\hline KOMPETENSI & \multicolumn{1}{|c|}{ DESKRIPSI KOMPETENSI } \\
\hline Sikap Spiritual & $1 . \begin{array}{l}\text { Menerima, menjalankan, dan menghargai ajaran agama yang } \\
\text { dianutnya }\end{array}$ \\
\hline Sikap Sosial & $\begin{array}{l}\text { Menunjukkan perilaku jujur, disiplin, tanggung jawab, santun, } \\
\text { peduli, dan percaya diri dalam berinteraksi dengan keluarga, teman, } \\
\text { guru, dan tetangganya }\end{array}$ \\
\hline Pengetahuan & 3. $\begin{array}{l}\text { Memahami pengetahuan faktual dengan cara mengamati dan } \\
\text { menanya berdasarkan rasa ingin tahu tentang dirinya, makhluk } \\
\text { ciptaan Tuhan dan kegiatannya, dan benda-benda yang dijumpainya } \\
\text { di rumah, di sekolah dan tempat bermain }\end{array}$ \\
\hline Keterampilan & 4. $\begin{array}{l}\text { Menyajikan pengetahuan faktual dalam bahasa yang jelas, } \\
\text { sistematis dan logis, dalam karya yang estetis, dalam gerakan yang } \\
\text { mencerminkan anak sehat, dan dalam tindakan yang mencerminkan } \\
\text { perilaku anak beriman dan berakhlak mulia }\end{array}$ \\
\hline
\end{tabular}

Tabel 13. Tingkat Kompetensi 3 (Tingkat Kelas V-VI SD/MI/SDLB/PAKET A)

\begin{tabular}{|c|c|}
\hline KOMPETENSI & DESKRIPSI KOMPETENSI \\
\hline Sikap Spiritual & $\begin{array}{l}\text { 1. Menerima, menjalankan, dan menghargai ajaran agama yang } \\
\text { dianutnya }\end{array}$ \\
\hline Sikap Sosial & $\begin{array}{l}\text { 2. Menunjukkan perilaku jujur, disiplin, tanggung jawab, santun, } \\
\text { peduli, dan percaya diri dalam berinteraksi dengan keluarga, teman, } \\
\text { guru, dan tetangganya serta cinta tanah Air }\end{array}$ \\
\hline Pengetahuan & $\begin{array}{l}\text { 3. Memahami pengetahuan faktual dan konseptual dengan cara } \\
\text { mengamati, menanya dan mencoba berdasarkan rasa ingin tahu } \\
\text { tentang dirinya, makhluk ciptaan Tuhan dan kegiatannya, dan } \\
\text { benda-benda yang dijumpainya di rumah, di sekolah dan tempat } \\
\text { bermain }\end{array}$ \\
\hline Keterampilan & $\begin{array}{l}\text { 4. Menyajikan pengetahuan faktual dan konseptual dalam bahasa yang } \\
\text { jelas, sistematis, logis dan kritis, dalam karya yang estetis, dalam } \\
\text { gerakan yang mencerminkan anak sehat, dan dalam tindakan yang } \\
\text { mencerminkan perilaku anak beriman dan berakhlak mulia }\end{array}$ \\
\hline
\end{tabular}

Tabel 14. Tingkat Kompetensi 4 (Tingkat Kelas VII-VIII SMP/MTs/SMPLB/PAKET B)

\begin{tabular}{|c|c|c|}
\hline KOMPETENSI & \multicolumn{1}{c|}{ DESKRIPSI KOMPETENSI } \\
\hline Sikap Spiritual & $1 . \quad$ Menghargai dan menghayati ajaran agama yang dianutnya \\
\hline Sikap Sosial & 2. $\begin{array}{l}\text { Menghargai dan menghayati perilaku jujur, disiplin, tanggung } \\
\text { jawab, peduli (toleransi, gotong royong), santun, percaya diri, } \\
\text { dalam berinteraksi secara efektif dengan lingkungan sosial dan } \\
\text { alam dalam jangkauan pergaulan dan keberadaannya }\end{array}$ \\
\hline Pengetahuan & $\begin{array}{l}\text { Memahami dan menerapkan pengetahuan (faktual, konseptual, dan } \\
\text { prosedural) berdasarkan rasa ingin tahunya tentang ilmu } \\
\text { pengetahuan, teknologi, seni, budaya terkait fenomena dan kejadian } \\
\text { tampak mata }\end{array}$ \\
\hline
\end{tabular}




\begin{tabular}{|c|c|}
\hline & 4. $\begin{array}{l}\text { Mengolah, menyaji, dan menalar dalam ranah konkret } \\
\text { (menggunakan, mengurai, merangkai, memodifikasi, dan membuat) } \\
\text { dan ranah abstrak (menulis, membaca, menghitung, menggambar, } \\
\text { Keterampilan }\end{array}$ \\
& sumber lain yang sama dalam sudut pandang/teori
\end{tabular}

Tabel 15. Tingkat Kompetensi 4A (Tingkat Kelas IX SMP/MTs/SMPLB/PAKET B)

\begin{tabular}{|c|c|c|}
\hline KOMPETENSI & \multicolumn{1}{|c|}{ DESKRIPSI KOMPETENSI } \\
\hline Sikap Spiritual & 1. & Menghargai dan menghayati ajaran agama yang dianutnya \\
\hline Sikap Sosial & $2 . \quad \begin{array}{l}\text { Menghargai dan menghayati perilaku jujur, disiplin, tanggung } \\
\text { jawab, peduli (toleransi, gotong royong), santun, percaya diri, } \\
\text { dalam berinteraksi secara efektif dengan lingkungan sosial dan } \\
\text { alam dalam jangkauan pergaulan dan keberadaannya }\end{array}$ \\
\hline Pengetahuan & $\begin{array}{l}\text { Memahami dan menerapkan pengetahuan (faktual, konseptual, dan } \\
\text { prosedural) berdasarkan rasa ingin tahunya tentang ilmu } \\
\text { pengetahuan, teknologi, seni, budaya terkait fenomena dan kejadian } \\
\text { tampak mata }\end{array}$ \\
\hline Keterampilan & $\begin{array}{l}\text { Mengolah, menyaji, dan menalar dalam ranah konkret } \\
\text { (menggunakan, mengurai, merangkai, memodifikasi, dan membuat) } \\
\text { dan ranah abstrak (menulis, membaca, menghitung, menggambar, } \\
\text { dan mengarang) sesuai dengan yang dipelajari di sekolah dan } \\
\text { sumber lain yang sama dalam sudut pandang/teori }\end{array}$ \\
\hline
\end{tabular}

Tabel 16. Tingkat Kompetensi 5 (Tingkat Kelas X-XI SMA/MA/SMALB/PAKET C)

\begin{tabular}{|c|c|}
\hline KOMPETENSI & DESKRIPSI KOMPETENSI \\
\hline Sikap Spiritual & 1. Menghayati dan mengamalkan ajaran agama yang dianutnya \\
\hline Sikap Sosial & $\begin{array}{l}\text { 2. Menghayati dan mengamalkan perilaku jujur, disiplin, tanggung } \\
\text { jawab, peduli (gotong royong, kerjasama, toleran, damai), santun, } \\
\text { responsif dan pro-aktif dan menunjukkan sikap sebagai bagian dari } \\
\text { solusi atas berbagai permasalahan dalam berinteraksi secara efektif } \\
\text { dengan lingkungan sosial dan alam serta dalam menempatkan diri } \\
\text { sebagai cerminan bangsa dalam pergaulan dunia }\end{array}$ \\
\hline Pengetahuan & $\begin{array}{l}\text { 3. Memahami, menerapkan, dan menganalisis pengetahuan faktual, } \\
\text { konseptual, prosedural, dan metakognitif berdasarkan rasa ingin } \\
\text { tahunya tentang ilmu pengetahuan, teknologi, seni, budaya, dan } \\
\text { humaniora dengan wawasan kemanusiaan, kebangsaan, } \\
\text { kenegaraan, dan peradaban terkait penyebab fenomena dan } \\
\text { kejadian, serta menerapkan pengetahuan prosedural pada bidang } \\
\text { kajian yang spesifik sesuai dengan bakat dan minatnya untuk } \\
\text { memecahkan masalah }\end{array}$ \\
\hline Keterampilan & $\begin{array}{l}\text { 4. Mengolah, menalar, dan menyaji dalam ranah konkret dan ranah } \\
\text { abstrak terkait dengan pengembangan dari yang dipelajarinya di } \\
\text { sekolah secara mandiri, bertindak secara efektif dan kreatif, serta } \\
\text { mampu menggunakan metoda sesuai dengan kaidah keilmuan }\end{array}$ \\
\hline
\end{tabular}




\begin{tabular}{|c|c|}
\hline KOMPETENSI & DESKRIPSI KOMPETENSI \\
\hline Sikap Spiritual & 1. Menghayati dan mengamalkan ajaran agama yang dianutnya \\
\hline Sikap Sosial & $\begin{array}{l}\text { 2. Menghayati dan mengamalkan perilaku jujur, disiplin, tanggung } \\
\text { jawab, peduli (gotong royong, kerjasama, toleran, damai), santun, } \\
\text { responsif dan pro-aktif dan menunjukkan sikap sebagai bagian dari } \\
\text { solusi atas berbagai permasalahan dalam berinteraksi secara efektif } \\
\text { dengan lingkungan sosial dan alam serta dalam menempatkan diri } \\
\text { sebagai cerminan bangsa dalam pergaulan dunia }\end{array}$ \\
\hline Pengetahuan & $\begin{array}{l}\text { 3. Memahami, menerapkan, dan menganalisis pengetahuan faktual, } \\
\text { konseptual, prosedural, dan metakognitif berdasarkan rasa ingin } \\
\text { tahunya tentang ilmu pengetahuan, teknologi, seni, budaya, dan } \\
\text { humaniora dalam wawasan kemanusiaan, kebangsaan, kenegaraan, } \\
\text { dan peradaban terkait penyebab fenomena dan kejadian dalam } \\
\text { bidang kerja yang spesifik untuk memecahkan masalah. }\end{array}$ \\
\hline Keterampilan & $\begin{array}{l}\text { 4. Mengolah, menalar, dan menyaji dalam ranah konkret dan ranah } \\
\text { abstrak terkait dengan pengembangan dari yang dipelajarinya di } \\
\text { sekolah secara mandiri, bertindak secara efektif dan kreatif, dan } \\
\text { mampu melaksanakan tugas spesifik di bawah pengawasan } \\
\text { langsung. }\end{array}$ \\
\hline
\end{tabular}

Tabel 18. Tingkat Kompetensi 6 (Tingkat Kelas XII SMA/MA/SMALB/PAKET C)

\begin{tabular}{|c|c|c|}
\hline KOMPETENSI & \multicolumn{1}{c|}{ DESKRIPSI KOMPETENSI } \\
\hline Sikap Spiritual & 1. Menghayati dan mengamalkan ajaran agama yang dianutnya \\
\hline Sikap Sosial & $\begin{array}{c}\text { 2. } \\
\text { Menghayati dan mengamalkan perilaku jujur, disiplin, tanggung } \\
\text { jawab, peduli (gotong royong, kerjasama, toleran, damai), santun, } \\
\text { responsif dan pro-aktif dan menunjukkan sikap sebagai bagian dari } \\
\text { solusi atas berbagai permasalahan dalam berinteraksi secara efektif } \\
\text { dengan lingkungan sosial dan alam serta dalam menempatkan diri } \\
\text { sebagai cerminan bangsa dalam pergaulan dunia }\end{array}$ \\
\hline Pengetahuan & $\begin{array}{l}\text { Memahami, menerapkan, menganalisis dan mengevaluasi } \\
\text { pengetahuan faktual, konseptual, prosedural, dan metakognitif } \\
\text { berdasarkan rasa ingin tahunya tentang ilmu pengetahuan, } \\
\text { teknologi, seni, budaya, dan humaniora engan wawasan } \\
\text { kemanusiaan, kebangsaan, kenegaraan, dan peradaban terkait } \\
\text { penyebab fenomena dan kejadian, serta menerapkan pengetahuan } \\
\text { prosedural pada bidang kajian yang spesifik sesuai dengan bakat } \\
\text { dan minatnya untuk memecahkan masalah }\end{array}$ \\
\hline Keterampilan & $\begin{array}{l}\text { Mengolah, menalar, menyaji, dan mencipta dalam ranah konkret } \\
\text { dan ranah abstrak terkait dengan pengembangan dari yang } \\
\text { dipelajarinya di sekolah secara mandiri serta bertindak secara } \\
\text { efektif dan kreatif, dan mampu menggunakan metoda sesuai dengan } \\
\text { kaidah keilmuan }\end{array}$ \\
\hline
\end{tabular}

Tabel 19. Tingkat Kompetensi 6 (Tingkat Kelas XII SMK/MAK/PAKET C KEJURUAN) 


\begin{tabular}{|c|c|}
\hline KOMPETENSI & DESKRIPSI KOMPETENSI \\
\hline Sikap Spiritual & 1. Menghayati dan mengamalkan ajaran agama yang dianutnya \\
\hline Sikap Sosial & $\begin{array}{l}\text { 2. Menghayati dan mengamalkan perilaku jujur, disiplin, tanggung } \\
\text { jawab, peduli (gotong royong, kerjasama, toleran, damai), santun, } \\
\text { responsif dan pro-aktif dan menunjukkan sikap sebagai bagian dari } \\
\text { solusi atas berbagai permasalahan dalam berinteraksi secara efektif } \\
\text { dengan lingkungan sosial dan alam serta dalam menempatkan diri } \\
\text { sebagai cerminan bangsa dalam pergaulan dunia. }\end{array}$ \\
\hline Pengetahuan & $\begin{array}{l}\text { 3. Memahami, menerapkan, menganalisis, dan mengevaluasi } \\
\text { pengetahuan faktual, konseptual, prosedural, dan metakognitif } \\
\text { dalam ilmu pengetahuan, teknologi, seni, budaya, dan humaniora } \\
\text { dengan wawasan kemanusiaan, kebangsaan, kenegaraan, dan } \\
\text { peradaban terkait penyebab fenomena dan kejadian dalam bidang } \\
\text { kerja yang spesifik untuk memecahkan masalah. } \\
\end{array}$ \\
\hline Keterampilan & $\begin{array}{l}\text { 4. Mengolah, menalar, menyaji, dan mencipta dalam ranah konkret } \\
\text { dan ranah abstrak terkait dengan pengembangan dari yang } \\
\text { dipelajarinya di sekolah secara mandiri, dan mampu melaksanakan } \\
\text { tugas spesifik di bawah pengawasan langsung }\end{array}$ \\
\hline
\end{tabular}

\section{c. Eksistensi Pendidikan Agama Islam dalam Kurikulum Nasional}

Selama ini pelaksanaan pendidikan agama yang berlangsung di sekolah masih mengalami banyak kelemahan. Menurut Mochtar Buchori pendidikan agama masih gagal, menurutnya kegagalan ini disebabkan karena praktik pendidikannya hanya memperhatikan aspek kognitif, dan mengabaikan pembinaan aspek afektif dan konatif-volitif, yakni kemauan dan tekad untuk mengamalkan nilai-nilai ajaran agama. Akibatnya terjadi kesenjangan antara pengetahuan dan pengamalan dalam kehidupan nilai agama. Atau dalam praktik pendidikan agama berubah menjadi pengajaran agama, sehingga tidak mampu membentuk pribadi-pribadi bermoral, ${ }^{17}$ padahal intisari dari pendidikan agama adalah pendidikan akhlah dan moral. ${ }^{18}$

Kenyataan tersebut ditegaskan kembali oleh menteri agama RI, Muhammad Maftuh Basyuni pada koran Tempo edisi tanggal 24 November 2004, beliau mengatakan bahwa pendidikan agama yang berlangsung saat ini cenderung lebih mengedepankan aspek kognisi (pemikiran) dari pada mengedepankan aspek afeksi (rasa) dan psikomotorik (tingkah laku).

17 Mochtar Buchori, Ilmu Pendidikan \& Praktik Pendidikan Dalam Renungan. (Yogyakarta: Tiara Wacana, 1994), hlm. 23

${ }^{18}$ Harun Nasution, Islam Dan Pendidikan Nasional, (Jakarta: Lembaga Penelitian IAIN Jakarta, 1983), hlm. 23 
Menurut Komaruddin Hidayat, pendidikan agama saat ini lebih berorientasi pada belajar tentang agama, sehingga hasilnya banyak orang yang mengetahui nilai-nilai ajaran agama, tetapi perilakunya tidak relevan dengan nilai-nilai ajaran agama yang diketahuinya. ${ }^{19}$

Amin Abdullah juga mengatakan bahwa pendidikan agama lebih banyak terkonsentrasi pada persoalan-persolan teoritis keagamaan yang bersifat kognitif dan kurang berkonsentrasi terhadap persoalan bagaimana mengubah pengetahuan agama yang kognitif menjadi bermakna dan bernilai yang perlu diinternalisasikan dalam peserta didik lewat berbagai cara, media dan forum. ${ }^{20}$

Di sisi lain, Mochtar Buchori juga menyatakan, bahwa kegiatan pendidikan agama yang berlangsung selama ini lebih banyak bersikap menyendiri, kurang berinteraksi dengan kegiatan-kegiatan pendidikan lainnya. Cara kerja semacam ini kurang efektif untuk keperluan penanaman suatu perangkat nilai yang kompleks. Karena itu seharusnya para guru atau pendidik agama berkerja sama dengan guru non-agama dalam pekerjaan sehari-hari. Cara tersebut agar program pendidikan agama dan non-agama dapat relevan dengan perkembangan dan perubahan sosial yang terjadi pada masyarakat. $^{21}$

Di lain pihak, Rasdijanah mengemukakan beberapa kelemahan pendidikan agama Islam di sekolah baik dalam pemahaman materi pendidikan agama Islam maupun dalam pelaksanaannya, yaitu:

1) Dalam bidang teologi, ada kecenderungan mengarah pada paham fatalistik.

2) Bidang akhlak berorientasi pada urusan sopan santun dan belum dipahami sebagai keseluruhan pribadi manusia beragama.

${ }^{19}$ Komarudin Hidayat, Memetakan Kembali Struktur Keilmuan Islam (Jakarta: Logos, 1999), hlm. 56

${ }^{20}$ Amin Abdullah, "Problem Epistemologis-Metodologis Pendidikan Islam", dalam Abdul Munir Mulkhan, et.alReligiusitas Iptek, (Yogyakarta: Pustaka Pelajar, 1988) hlm. 24

${ }^{21}$ Mochtar Buchori, Op.Cit. Hlm. 24 
3) Bidang ibadah diajarkan sebagai kegiatan rutin agama dan kurang ditekankan sebagai proses pembentukan kepribadian.

4) Dalam bidang Fiqih cenderung dipelajari sebagai tata aturan yang tidak akan berubah sepanjang masa, dan kurang memahami dinamika dan jiwa hukum Islam.

5) Agama Islam cenderung diajarkan sebagai dogma dan kurang mengembangkan rasionalitas serta kecintaan pada kemajuan ilmu pengetahuan.

6) Orientasi mempelajari Al-Quran masih cenderung pada kemampuan membaca teks, belum mengarah pada pemahaman arti dan penggalian makna. $^{22}$

Towaf telah mengamati adanya kelemahan-kelemahan pendidikan agama Islam di sekolah, antara lain:

1) Pendekatan masih cenderung normatif, dalam arti pendidikan agama menyajikan norma-norma yang sering kali tanpa ilustrasi konteks sosial budaya, sehingga peserta didik kurang menghayati nilai-nilai agama sebagai nilai yang hidup dalam keseharian.

2) Kurikulum pendidikan agama Islam yang dirancang di sekolah sebenarnya lebih menawarkan minimum kompetensi atau minimum informasi, tetapi pihak guru PAI sering kali terpaku padanya, sehingga semangat untuk memperkaya kurikulum dengan pengalaman belajar yang bervariasi kurang tumbuh.

3) Guru PAI kurang berupaya menggali berbagai metode yang mungkin bisa dipakai untuk pendidikan agama, sehingga pelaksanaan pembelajaran cenderung monoton.

4) Keterbatasan sarana dan prasarana sering kali diabaikan, sehingga pengelolaannya cenderung seadanya. Pendidikan agama yang diklaim

${ }^{22}$ Rasdijanah, Butir-butir Pengarahan Dirjen Binbaga Islam pada Pelatihan Peningkatan Wawasan Ilmu Pengetahuan dan Kependidikan Bagi Dosen PAI di Perguruan Tinggi Umum. (Bandung: 11 September 1995). 
sebagai aspek yang penting sering kali kurang diberi prioritas dalam urusan fasilitas. $^{23}$

Berangkat dari itulah maka kemudian pemerintah melalui kementrian pendidikan dan kebudayaan melakukan pembaharuan pendidikan nasional dengan munculnya K13 yang dirasa dapat menjawab berbagai kritik terhadap sisitem pendidikan di Indonesia, terlebih menyangkut pendidikan akhlak dan budi pekerti yang notabennya menjadi beban dari mata pelajaran agama. Maka dengan tujuan yang telah dirumuskan, diputuskan bahwa penanaman karakter kepada peserta didik menjadi kewajiban semua guru dalam pembelajarannya. Hal ini diharapkan bahwa pendidikan karakter dapat dilakukan lebih intensif terhadap peserta didik.

Dari uraian di atas dapat dipahami bahwa berbagai kritik dan sekaligus yang menjadi kelemahan dari pelaksanaan pendidikan agama Islam lebih banyak bermuara pada aspek metodologi pembelajaran PAI dan orientasinya yang lebih normatif, teoritis dan kognitif, termasuk di dalamnya aspek gurunya yang kurang mampu mengaitkan dan berinteraksi dengan mata pelajaran dan guru nonpendidikan agama. Aspek lainnya yang banyak disoroti adalah menyangkut aspek muatan kurikulum atau materi pendidikan agama, sarana pendidikan, termasuk di dalamnya buku-buku dan bahan ajar pendidikan agama.

Terkait dengan analisis penulis, dapat diketahui bahwa dari segi isi materi kurikulum, pendidikan agama kurang menggabungkan materi dengan konteks sosial yang terjadi, materi pendidikan hanya berisi sekedar informasi saja, sehingga hasil yang diperoleh dari anak didik hanya pengetahuan konitif saja yang di dapat, aspek afektif dan psikomotorik akan terabaikan. Jadi jangan heran apabila anak pintar dalam teori tapi minim dalam pelaksanaanya.

Maka dari itu adanya kurikulum 2013 berbasis karakter akan membantu tercapainya tujuan pendidikan nasional dan tujuan pendidikan agama islam secara khusus dalam menciptakan peserta didik yang memiliki keimanan kepada Tuhan yang Maha Esa dan berakhlak atau berbudi pekerti luhur. Namun dalam prakteknya tidak menutup kemungkin adanya kelemahan-kelemah dan untuk itu

${ }^{23}$ Siti Malikhah Thowaf, "Pembinaan Kampus Sebagai Lembaga Pendidikan Ilmiah Edukatif yang Religius. "Makalah Disajikan dalam Konvensi Pendidikan Indonesia III. Ujung Pandang, 4-7 Maret 1996. 
pemerintah dan juga pelaksana pendidikan harus terus berupaya melakukan perbaikan-perbaikan yang sifatnya berkelanjutan.

\section{KESIMPULAN}

Dari urainya di atas dapat ditarik sebuah kesimpulan mengenai analisis Standar Kompetensi Lulusan dan Standar Isi Pendidikan Agama Islam dalam kurikulum nasional adalah bahwa status Pendidikan Agama Islam terintegrasi dalam kurikulum nasional sebagai sebuah mata pelajaran yang sifatnya wajib bagi seluruh jenjang pendidikan serta dalam pembaharuannya pendidikan akhlak sebagai tujuan utama pedidikan Islam sekarang ini telah menjadi keharusan setiap mata pelajaran. Selain itu Standar Kopetensi Lulusan dan Standar Isi Pendidikan Agama Islam telah tercantum dalam perundang-undangan pendidikan di Indonesia melalu Perarutan Menteri Pendidikan Nasional yang kemudian dapat dikembangkan oleh masing-masing sekolah. Pada kenyataannya dalam pelaksanaan Pendidikan Agama Islam di Sekolah masih memiliki berbagai kendala-kenadala yang menyertainya, sehingga perlu dilakukan perbaikan yang terus menerus sehingga Pendidikan Agama Islam di negeri ini dapat mencapai tujuannya.

\section{REFERENSI}

Muhaimin, 2003 Wacana Pengembangan Pendidikan Islam. Yogyakarta: Pustaka Pelajar

Ahmad Tafsir, 2014, Pengembangan Pendidikan Agama Islam Berbasis Multidisipliner, Malang; Seminar

Azra. Azumardi, 2003, Agama dan Pemberantasan Korupsi. Harian Kompas

Muhaimin, 2010, Pengembangan Kurikulum Pendidikan Agama Islam di Sekolah, Madrasah, Dan Perguruan Tinggi, Jakarta: PT. RajaGrafindo

Undang-undang RI. No. 20 tahun 2003, Tentang Sistem Pendidikan Nasional. Bandung: Citra Umbara

Peraturan Pemerintah Republik Indonesia Nomor 19 Tahun 2005 Tentang Standar Nasional Pendidikan

Peraturan Pemerintah Republik Indonesia Nomor 32 Tahun 2013 Tentang Perubahan Atas Peraturan Pemerintah Nomor 19 Tahun 2005 Tentang Standar Nasional Pendidikan 
Soebahar. Abd. Halim, 2013, Kebijakan Pendidikan Islam dari Ordinasi Guru Sampai UU Sisdiknas, Jakarta: Rajawali Pres

Ramayulis, 2001, Metodologi Pengajaran Agama Islam, Jakarta: Kalam Mulia

Tim Pengembang Ilmu Pendidikan, 2007, Ilmu dan Aplikasi Pendidikan, Bandung:Fakultas Ilmu Pendikan (FIP) Universitas Pendidikan Indonesia (UPI)

Depdikbud, 1996 Peraturan Pelaksanaan Sistem Pendidikan Nasional, Jakarta, Armas Duta Jaya

Lampiran Peraturan Menteri Pendidikan Nasional Nomor 22 Tahun 2006 tentang Standar Isi

Lampiran Peraturan Menteri Pendidikan dan Kebudayaan Nomor 64 Tahun 2013 tentang Standar Isi.

Lampiran Peraturan Menteri Pendidikan dan Kebudayaan Nomor 54 Tahun 2013 tentang Standar Kompetensi Lulusan.

Wisyastono. Herry, 2014, Pengembangan Kurikulum Di Era Otonomi Daerah, Jakarta: PT. Bumi Aksara

E. Mulyasa, 2008, Kurikulum Tingkat SatuanPendidikanKemandirian Guru danKepalaSekolah, Jakarta: Bumiaksara, cet I

Buchori. Mochtar, 1994, Ilmu Pendidikan \& Praktik Pendidikan Dalam Renungan. Yogyakarta: Tiara Wacana

Nasution. Harun, 1983, Islam Dan Pendidikan Nasional, Jakarta: Lembaga Penelitian IAIN Jakarta

Hidayat. Komarudin, 1999, Memetakan Kembali Struktur Keilmuan Islam, Jakarta: Logos

Abdullah. Amin, 1988, "Problem Epistemologis-Metodologis Pendidikan Islam", dalam Abdul Munir Mulkhan, et.al Religiusitas Iptek, Yogyakarta: Pustaka Pelajar

Rasdijanah, 1999, Butir-butir Pengarahan Dirjen Binbaga Islam pada Pelatihan Peningkatan Wawasan Ilmu Pengetahuan dan Kependidikan Bagi Dosen PAI di Perguruan Tinggi Umum. Bandung:

Siti Malikhah Thowaf, 1996"Pembinaan Kampus Sebagai Lembaga Pendidikan Ilmiah Edukatif yang Religius." Makalah Disajikan dalam Konvensi Pendidikan Indonesia III. Ujung Pandang 